\title{
A micro-political perspective on subsidiary initiative- taking: Evidence from German-owned subsidiaries in
}

France

\section{Christoph Dörrenbächer}

Department of International Business \& Management, University of Groningen, Landleven 5, 9700 AV Groningen, The Netherlands,

Tel.: ++ 3150363 7338; fax: ++ 3150363 3720,

C.Dorrenbacher@rug.nl

Mike Geppert

School of Management, University of Surrey Guildford, GU2 7XH, U.K.

Tel: +44 (0)1483 683100 Fax: +44 (0)1483 689511

m.geppert@surrey.ac.uk 


\title{
A micro-political perspective on subsidiary initiative- taking: Evidence from German-owned subsidiaries in France.
}

\begin{abstract}
As classical micro-political studies have shown, management behavior is not only constrained or enabled by certain cultural, structural and institutional patterns, but is shaped by individual interests and actor rationales. Based on the assumption that actors are neither the organs of given structures nor acting fully autonomously, the paper highlights how key foreign subsidiary managers interpret and integrate individual, socio-political, organizational as well as some home and host country factors into distinct subsidiary initiatives, which they then try to accomplish in negotiations with the headquarters. Empirically the paper builds on three explorative case studies undertaken in German-owned subsidiaries in France, covering all main forms of subsidiary initiatives (local, global and MNC internal subsidiary initiatives).
\end{abstract}

\section{Keywords:}

Multinational Corporations, Subsidiary Initiative, Foreign Subsidiary Management, Headquarters-Subsidiary Relationships

\section{Introduction}

There is a long tradition of functional-structuralism in international business research. Classical studies such as those by Vernon (1966), Johanson and Vahlne (1977) and Dunning (1979) postulated a strong asymmetry between the headquarters (HQ) and its subsidiaries, with subsidiary development mainly seen as a HQ driven processes. Newer studies in the field offered by authors such as White and Poynter (1984), Birkinshaw et al. (see e.g. Birkinshaw, 2000, Birkinshaw and Hood, 1998) and Jarillo and Martínez (1990) have shown that subsidiaries as well as their entrepreneurial initiatives do play a more important role not only in the development of individual subsidiaries but also in the development of the multinational corporation (MNC) as a whole. However, what those scholars neglect is the role of key actors and the micro-political dimensions of subsidiary initiative and subsidiary development. Despite early claims that the "... research thrust should be directed towards the personal motivation of employees to pursue initiatives" (Birkinshaw 1997: 227), the interests, rationalities and behaviours of top foreign subsidiary managers with regard to subsidiary initiatives are still underexplored. 
In this paper, we will go beyond structuralist approaches in discussing subsidiary initiatives by exploring the differentiating role of top foreign subsidiary managers' individual interests and agency in HQ-subsidiary negotiations. Thereby the paper aims to contribute to the further understanding of multinational corporations as micro-political systems as postulated by Forsgren (1990) and more recently strongly emphasized e.g. by Bélanger and Edwards (2006), Dörrenbächer and Geppert (2006), Edwards and Kuruvilla (2005), Ferner et al. (2006), Forsgren et al. (2005) and Morgan and Kristensen (2006).

Following Egelhoff et al. (1998: 215) subsidiary development manifests itself in terms of roles or mandates a subsidiary earns or captures within the MNC. Thereby different kinds of subsidiary initiatives, defined as "entrepreneurial activities carried out by the foreign subsidiaries of multinational corporations" (Birkinshaw and Ridderstråle, 1999:14) are considered to exert a great influence. Following Birkinshaw (1997:208-210) these initiatives are directed either to the local, the global or the internal MNC market. Focusing on these three types of subsidiary initiatives, the paper will highlight the pivotal role of top subsidiaries managers' interests in such initiatives as well as their skills to mobilise resources to support such initiatives in micro-political negotiations with the HQ. This leads us to two distinct questions which will be analysed by applying qualitative research methods:

1. How are initiatives taken by top foreign subsidiary managers to gain further mandates or new roles linked with their socio-political and biographical backgrounds encompassing e.g. their nationality, their individual career interests and professional experiences?

2. What sort of tactical and social skills do top subsidiary managers apply in pursuing such initiatives in negotiations with their HQs?

Taking such a micro-political perspective on subsidiary initiatives and subsidiary development creates a need to eclectically combine different streams of literature (Clark, 2000; Sorge, 2005). Over the next chapters we draw on theories from rather different specialized fields with different levels of analysis, such as strategic and resource based views on subsidiary development processes, comparative institutionalist approaches which discuss the local embeddedness of organizational subunits as well as HRM-related research interested in staffing and careers across national borders.

The rest of the paper is organized as follows. First we will discuss the contributions and limits of current research, especially of so-called "evolutionary" and comparative institutionalist studies of the multinational corporation. We then discuss the literature on managerial interests and career orientations within the MNC, building up a framework to study the role of agency in subsidiary initiatives. Next to a brief overview about our research design and methodology, we present three explorative case studies. The case studies stress the active role of top foreign subsidiary managers both in the formation 
as well as in the accomplishment of such initiatives in negotiations with the HQ, illustrating trajectories of local, global and internally oriented subsidiary initiatives. This is followed by discussing the theoretical implications of our case study evidence, focusing on the subsidiary initiative literature. The final section concludes with a discussion of the managerial implications and limitations of this study and ideas for further research.

\section{Contributions and Limits of Evolutionary and Comparative Institutionalist}

\section{Research}

Research in international business and management has been for a long time predominantly concerned with technological and economic constraints on rational information-processing and decision-making in MNCs. Scholars have focused on issues such as successful FDI (see e.g. Teece, 1992, Vernon, 1966) or efficient adoptions and transfers of technologies and organizational structures (see e.g. Buckley, 1996; Casson, 1997; Egelhoff, 1993). In contrast to this research, evolutionary studies of the MNC concentrate mainly on how managerial strategies and the organizational design of the MNC are shaped by more or less unstable and uncertain international business environment contingencies, driving MNCs towards a specific best practice called the transnational solution (e.g. Bartlett and Ghoshal, 1989). This increasingly dominant paradigm was criticized for developing a rather narrow view of MNC management by focusing mainly on North-American multinationals, having a unilateral bias and concentrating predominantly on international expansion (Westney and Zaheer, 2001). However, the idea that an increasingly universal rationality is guiding managerial decisions in MNCs has also been questioned from various other perspectives. Some scholars, such as Birkinshaw (2000) and Birkinshaw and Hood (1998), follow to some extent the evolutionary logic, but stress that MNCs cannot be understood as homogenous organizational units, centrally controlled by the $\mathrm{HQ}$, especially when they operate in a highly complex global environment. Here managerial decision making, autonomy and entrepreneurship of subsidiaries are seen as crucial to gain competitive advantages and enhancements of mandates (ibid). Other researchers adopted Hofstede's approach (e.g. Cooper, 2003; Watson et al., 1993) and emphasize that unique assumptions and converging rationalities in MNCs are unrealistic because the subsidiary rationales remains strongly shaped by particular national norms and values of the host country culture.

Similarly to the latter, comparative institutionalism stresses the diversity of rationalities, organizational forms and structures. The key interest of this approach, however, is not so much in the socialization of individual decisionmakers in a certain national context, but how managerial decisions are influenced by the institutions of the nation state from which the MNC originates (Ruigrok and van Tulder, 1995; Whitley, 2001). It is stressed that reorganization 
of subsidiaries related to merger and acquisitions (e.g. Child et al., 2001), the transfer of HRM practices (e.g. Almond and Ferner, 2006; Gunnigle et al., 2002), coordination and control (Ferner, 2000; Harzing and Sorge, 2003) and subsidiary work systems (Geppert et al., 2003) are heavily shaped by key elements of the MNC's home country institutions, such as the financial, the educational and the industrial relations systems. Cross-national comparisons show why and how managerial decisions are related to certain home country institutional features, for example, how US MNCs tend to be driven by shortterm financial interests, compared to German and Japanese MNCs where decisions are more long-term oriented (see e.g. Almond and Ferner, 2006; Sharpe, 2001).

Table 1 about here

Based on early insights by Westney (1993) and Kostova (1999), it was only rather recently that comparative institutionalists began to redirect their analytical interests towards host country and third country influences, especially on the management of the subsidiaries (see e.g. Dörrenbächer, 2004; Kristensen and Zeitlin, 2005). This can be seen, on the one hand, as a further development of comparative institutionalism by stressing that the degree of host country embeddedness varies between different host countries and, thus, how much strategic choice and local decision-making autonomy subsidiary managers have in a certain host country, e.g. by comparing highly institutionally embedded German with less institutionally embedded British subsidiaries in the same industrial sector (see e.g. Geppert et al., 2003) or considering influences of highly fragmented business systems, such as in Venezuelan, on MNCs operating in different industrial sectors (Marquez, 2005). On the other hand, these studies can also be read as a critique of early comparative institutionalist studies. It was found that in certain host country contexts local management decides only to implement certain elements of 'best practices' and ideas developed in the home country, as stressed e.g. by Dörrenbächer's (2004), analysis of the extent to which German MNCs flee or export the so called 'German production model' when operating in the context of post-socialist Hungary. Other authors see more heterogeneity of home country influences through contingencies such as subsidiary size, industrial sector and the MNC's internationalization experience (e.g. Noorderhaven and Harzing, 2003).

In summary, compared to many mainstream studies on the MNC which concentrate on various environmental pressures towards global convergence of organizational strategies and structures, the most important contribution of comparative institutionalist research is to show the remaining importance of 
contextual rationalities, shaped by home and host country institutions. However, there are further contributions in the field that criticize conventional comparative studies for concentrating either on the home country or on the host country logic. It is therefore demanded that future research should rather look at the issue of 'hybridization' which means to analyze how home and host country influences come together (e.g. Becker-Ritterspach, 2006; Marquez, 2005) or react with each other (Sorge, 2005). What is of a greater importance for this paper however is a new research agenda proposed by Morgan (2001). He suggests that future research should also consider actors and contexts beyond national institutional influences and analyze dynamic and conflicting issues in emerging 'transnational social spaces' within and outside MNCs. Even when new conceptual developments give some room for applying a more actorcentered approach, the focus of analysis remains largely within the established structuralist tradition.

These overall conceptual developments are also mirrored in the more specific literature on subsidiary initiative-taking. Aside from papers that classify different types of subsidiary initiatives (Birkinshaw 1997) and others that look at the initiative process (e.g. Delany 1998), most academic work in the field concentrates on structural determinants of subsidiary initiatives. Following a recent overview by Verbeke at al. (2007) it is the various impacts from the MNC context, the subsidiary context and the local environment that influence subsidiary initiative-taking (for an overview see table 2).

Table 2 about here

However, what is missing here is a more bottom-up view of how actors (in particular top foreign subsidiary managers) actively influence subsidiary initiative-taking and what role their interests, socio-political backgrounds and social skills play.

\section{The Role of Agency in Subsidiary Initiatives}

Exploring the role of agency in subsidiary initiatives and subsidiary development requires, first and foremost, a clarification of the actor concept applied. Following the very basic premises of the micro-political approach (Burns 1961/1962, March 1962), we see actors and actors' organizational behavior as characterized basically by the demands an actor makes on the corporation and 
by the strategies employed to realize these demands. We assume that actors are neither the executive organs of given structures, nor fully autonomous (Tempel and Walgenbach, 2003). Instead we see actors as bound to rules, restrictions and resources. However such structural ties do not foreclose systematic and individual variations in actor demands and behaviors. Systematic variations might occur due to different functional or hierarchical backgrounds in organizations, to different educational and professional backgrounds (Pfeffer, 1983; Fligstein, 1990) and, in the case of MNCs, to different subunit, national and cultural backgrounds. Individual variations in actors' demands and strategies might occur due to the fact that the organizational behavior of actors is always taking into account the individual interests of the actor (Küpper and Felsch, 2000). These interests are often described as being closely related to autonomy, power and career ambitions. However, individual interests might also be shaped by group dynamics (Lee and Lawrence, 1985) or extra-organizational motivations such as altruistic beliefs (Ortmann, 1998) and personal identity constructions (Weick, 1995).

We assume that the basic concept of social agency also holds true when looking at key foreign subsidiary managers taking initiatives. Basically, foreign subsidiary managers have to fulfill three different tasks, as: sensors and interpreters of local opportunities, builders of local resources, and contributors to and active participants in global strategy developments within the MNC (see e.g. Ferner, 2000; Birkinshaw, 2000). To what extend and with what basic orientation key foreign subsidiary managers translate these different tasks into individual initiatives does not only depend on the different contexts they operate in but also on the particular socio-political and biographical backgrounds of key actors as specified in figure 1 below. Relevant characteristics here extend to the interplay of key foreign subsidiary managers' nationality, career ambitions and career orientations.

Figure 1 about here

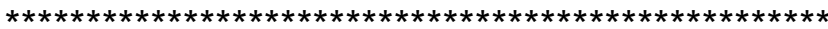

Nationality: Following a well-established categorization, foreign subsidiary managers are either parent country nationals (PCNs or expatriates), host country nationals (HCNs), or third country nationals (TCNs) (Harzing, 1999; Scullion and Collings, 2006; Tarique et al. 2006). These different types of staff are ascribed different orientations or perceptions (Chini et al., 2005). Usually $\mathrm{PCNs}$ are seen as strongly following a HQ orientation due to their familiarity with the MNC's overall goals, policies and practices (Black and Gregersen, 1992). Very often they are seen as most efficient in exercising HQ control over the subsidiary. However this strong $\mathrm{HQ}$ orientation is only with $\mathrm{PCNs}$ that are 
not going native, e.g. by marrying a local partner, converting to the locally dominant religion, or taking up permanent local residence, as Loveridge (2006) stresses. HCNs, on the other hand, are seen as basically having a local subsidiary orientation, due to their socialization in the host country and their familiarity with the social, political and economic environment of the host country (Harvey et al., 1999). However following Petersen et al. (1996; 2000) a strong local subsidiary orientation is only with HCNs that do not have international career options. Whether such options exist, basically relates to the career schemes of the MNC and the skills of the HCN. TCNs are often ascribed a generically more balanced orientation between the $\mathrm{HQ}$ and the local subsidiary. However following Harzing (1999), their number is very small compared to PCNs and HNCs. Finally there is a growing number of foreign subsidiary managers, that does not fit into any of the categories discussed above, due to their bi-national, bi-lingual and/or bi-cultural biography. However to what degree these 'hybrids' do follow a local subsidiary or a HQ orientation and how this relates to their biography is still an open question we will refer to in our empirical discussion.

Career aspirations: In addition to nationality, the individual career aspirations of a top foreign subsidiary manager might also influence her or his positioning between a local subsidiary and a HQ orientation. Career aspirations have the potential to sustain, weaken or break an orientation defined by nationality. Classic career development models, postulate that the career aspirations of an individual manager depend on her/his career stage, with the early career years aiming at becoming established, the mid career years defined as a phase of career advancement and maintenance and the late career years as adjustment to retirement (Hall and Nougain, 1968). Newer research has shown that these concepts, which strongly correlate career aspirations with age, are too rigid to cover the blurring of standard biographies. Thus, Hall (2002) proposes a more open framework, relating career aspirations of individuals to perceptions of whether they see themselves as being established or not. Whether or not a top foreign subsidiary manager of an MNC is satisfied with his or her present career stage depends on various individual factors such as age, family situation, health, self assessment of talents etc. These individual characteristics, however, have to be related to organizational features, such as MNC specific career schemes and staffing policies, appraisal and compensation policies as well as support systems (Peltonen, 1993; Stahl et al., 2002; Bolino, 2006). Furthermore, situational features associated with specific career steps have to be taken into account, most prominently issues of geographic mobility (Mayrhofer, 1996), anticipated work conditions (work atmosphere, burden of work etc.) and changes in tasks and responsibilities.

Career orientations: Following Schein (1978/1990), career anchors inside the person (defined by self-perceived talents and abilities, by self-perceived motives and needs as well as by self-perceived attitudes and values) function as driving and constraining forces on career decisions and choices. Based on these 
premises, Moss Kanter (1989) distinguishes among bureaucratic, professional and entrepreneurial career orientations, with bureaucratic orientations being defined by the logic of advancement in the hierarchy of a given organization, professional orientations based on the logic of increasing knowledge and reputation and the entrepreneurial orientations based on the logic of increasing autonomy and innovation. As we will see in the case studies below, these career logics are important to understanding the kind of initiatives that key foreign subsidiary managers undertake.

Contexts: The impact of these socio-political and biographical actor characteristics on subsidiary initiatives and related HQ-subsidiary negotiations has to be seen in relation to the corporate (MNC), the subsidiary and the local (institutional) contexts (Verbeke et al., 2007). Some relevant influences from the corporate (MNC) context on the cognitive orientation of key foreign subsidiary managers have already been mentioned, such as career schemes, staffing and compensation policies. In addition to these HRM-related factors, some more general organizational settings might have an influence on key foreign subsidiary manager's initiative-taking, such as HQ policy on intra-firm competition or the shape of headquarters-subsidiary relationships. ${ }^{1}$ The subsidiary context accounts for the resources and capabilities available to a subsidiary. Managerial expertise (Rugman and Douglas, 1986), specific product portfolios (Hood et al., 1994), specialized technologies (Egelhoff et al., 1998), and internal R\&D processes (Pearce, 1999; Florida, 1997; Taggert, 1998) are all seen as having a strong influence on the opportunities of subsidiaries and their managers to successfully develop initiatives and pursue them in negotiations with the HQ. Finally, the local (institutional) context consists of the location specific advantages of the host country (Dörrenbächer and Gammelgaard 2006), related government policy and national institutional settings (Djelic and Quack, 2003).

\section{Data and Methodology}

The case studies presented below are taken from an ongoing research project on entrepreneurship in German multinational corporations. Focusing on French affiliates, the project aims at elucidating actor rationales in processes of subsidiary development. The research design is exploratory and mainly based

\footnotetext{
1 Changes in the institutional environment are considered as having a strong impact here (Fligstein, 1990; Useem, 1996). In coordinated market economies, such as Germany, an increasing internationalization of capital markets led to stronger shareholder value pressures which have biting impact on the rules according to which subsidiary initiatives are evaluated by HQs (Vitols, 2004; Jürgens et al., 2000; Tainio et al., 2001). These developments have the potential, as this study shows, to trigger a multitude of interest driven conflicts (Seo and Creed, 2002). Key foreign subsidiary managers might also find their basic career orientations as well as their practices and social skills developed under the 'old regime' increasingly challenged by the financial conception of the firm (Fligstein, 1990).
} 
on qualitative interviews conducted in French subsidiaries, covering different industries, HQ policies and subsidiary management nationalities. The three case studies presented here are selected from a first round of interviews. Based on intensive preparatory work, semi-structured interviews, lasting between two and three hours, were conducted with top foreign subsidiary managers. The interviews were taped, transcribed and triangulated with the analysis of various documents. In order to appropriately frame and triangulate the subsidiary manager's perspectives, prioritized in this paper, the HQ view was explored either through interviews or through an intensive study of secondary sources.

Given the exploratory nature of this paper, the cases each represent one of the three main types of subsidiary initiatives as defined by Birkinshaw (1997). Case one represents a set of local subsidiary initiatives, case two focuses on a global market initiative, and the initiative in case three is focused on the MNC internal market.

All case studies were drawn from German MNCs that are currently undergoing strong changes in the direction of a more pronounced shareholder value orientation, more or less 'alienating' these firms from traditions of the so-called 'German model'. ${ }^{2}$ The fact that the case studies are rooted in institutionalizing rather then in institutionalized arenas (see e.g. Djelic and Quack, 2003); means that there are significant and multiple incentives for key foreign subsidiary managers to come up with initiatives aimed at further developing their subsidiary. This is especially true for the key managers of French subsidiaries. Despite the fact that France and Germany differ significantly with regard to several key national business systems features, ${ }^{3}$ many scholars group Germany and France as coordinated market economies (e.g. Albert, 1991; Whitley, 2001). Both are economies that combine long term economic orientation with strong social equality and highly influential corporatist actors and government. Therefore, choosing France as a host country limits the potentially distorting effects that a weaker regulatory and welfare state framework might have on subsidiary management initiatives.

\section{Case Studies}

Case 1: A set of local market initiatives

\footnotetext{
${ }^{2}$ The German Model is usually characterized by highly regulated labor relations, patient capital and a general orientation of the management towards technical aims (e.g. Katzenstein 1980, Albert 1991, Streeck 1997).

${ }^{3}$ A recent overview by Kleiner (2004) displays France as specifically strong in the centralization of the economy, in educational stratification as well as in the impact of social networks.
} 
A middle-aged French Chief Executive Officer (CEO) of a subsidiary providing marketing and maintenance services for a German supplier of agricultural machinery issues a set of initiatives to develop his subsidiary step by step. He displays a rather entrepreneurial career orientation targeting business opportunities in the local market. The primary objective of his local initiatives is to gain the cooperation of $H Q$ for which his main resource is his personal relationships with several important $H Q$ managers.

After receiving a degree in mechanical engineering, this French manager started his career with a one-year internship at the $\mathrm{HQ}$ of the family owned German MNC. After returning to France, he worked in a company that imported the products of the German MNC, further consolidating the mutual relationship. When serious managerial problems occurred at the French importer, the German MNC took over this business in 1987 and appointed its former intern as CEO of the newly acquired sales and maintenance subsidiary.

At first, the new CEO concentrated on building up state-of-the-art practices in his subsidiary to better fulfill the tasks assigned by $\mathrm{HQ}$ (primarily market screening, market communication, distribution and product adaptation). An important initiative of the newly appointed CEO was the relocation of the subsidiary from a larger city close to Paris to a more rural area. The aim of the relocation was to create more physical space to expand business activities. However, the 1992 agricultural state reform caused tremendous cutbacks in demand for agricultural machinery and stopped the subsidiary's growth. The company's turnover collapsed in the following years, which led to a massive reduction of staff from about 70 to 35 .

With on-site support from one of the sons from the owner family (now one of the managing directors of the MNC), the French CEO started looking for new business opportunities in France. This led to an initiative to out-compete the French service subsidiary of another German MNC that produces a complementary range of agricultural machinery. In the end, the French service subsidiary of the other German MNC was closed and the task was taken over by the French CEO and his subsidiary.

After taking over the new task, the French subsidiary almost doubled in size, gaining critical mass for more entrepreneurial activities. This time, the stagnation of the German market as well as the dominant position of the German MNC in its home market led to shift in strategy towards an increased company presence in the French market. Although the French CEO and HQ had reached a general consensus that the development of French market should receive greater attention within the whole MNC, the HQ appeared to be rather reluctant to support this locally developed strategy. The French CEO did not stop to lobby for this move and started to change internal practices within the subsidiary, enabling it to better exploit the French market. He also took the 
initiative to hire German speaking product managers for every important product to improve the adaptation of products and services as well as the development of new products for the local market. These measures were rather successful, and they expanded the French subsidiary's competencies in product development.

Another initiative of the French CEO aimed at the local market was his so-called 'market communication' project. Initially, the HQ was not so enthusiastic about the idea, which was to develop a product catalogue with information on all products offered by the company in France. So far information on products offered was provided in separate product information sheets. However, the increased reputation of the French CEO, close personal relationships to one of the owner-managers, (the manager who once was expatriated for a year to the French subsidiary) together with a supportive organizational culture led to the development of high-trust relationships, enabling the French CEO to get the necessary HQ support for his initiatives. In the end, the new catalogue turned out to be a great success, and $\mathrm{HQ}$ decided to adopt the idea for the German market.

Despite his increasing reputation and influence in the HQ, the French CEO was never interested in a career at $\mathrm{HQ}$ for several reasons. One reason for this was that the family-run MNC offered only a few top management positions to nonfamily members. Moreover, the French CEO could easily gratify his entrepreneurial orientation by addressing the many challenging tasks he encountered in developing the French subsidiary. Thus the French CEO recently obtained the HQ's approval on a new initiative to relocate the subsidiary again to a more spacious location, which was seen as the foundation for future growth and subsidiary development.

\section{Case 2: A Global market initiative}

A German expatriate manager close to retirement, with some international experience and a strong engineering background, successfully meets the challenging requirements of a new HQ-assigned mandate, by drawing on subsidiary related resources (e.g. in R\&D) and his personal social network. Spurred by his professional ambitions, he developed initiatives to meet some of the crucial technological challenges associated with the new mandate. However, he was not able to expand these achievements at a more global level, because of an increasingly strict shareholder value orientation of the HQ, which created a hostile micro-political climate for such initiatives.

Technical and organizational challenges were this 57-year-old manager's basic rationale for becoming the CEO of a newly-established French subsidiary of a 
Bavarian automotive supplier. Despite his considerable experience in similar positions in different national and foreign subsidiaries of the German conglomerate to which the Bavarian automotive supplier belongs, it ultimately proved difficult to fulfill the requirements of this HQ-assigned mandate. Integrated into one of the most innovative car production networks worldwide, the French subsidiary was supposed to ramp up a blueprint for using new material in mass car production. Immediately after production started, it became clear that basic process innovations were needed to meet the quality criteria set by the car's end producer. A painful trial-and-error process was required to cope with these complex technical demands.

Accordingly, the French CEO negotiated with the $\mathrm{HQ}$ for additional financial resources. However his requests for significant financial investments were rejected by the divisional HQ in Bavaria with phrases such as: 'Don't bother us, it's your job to fix the problems there'. This refusal of power holders in the HQ to support this challenging, yet very promising project, appeared to be related mainly to a dramatic shift in the overall managerial orientations of the conglomerate and its automotive supply division. Once technologically driven, the company ran into deep trouble due to several ill-fated financial speculations and other irregularities in the behavior of top management. As a result, a new CEO was appointed at the demand of the company's major shareholders. Because the new CEO was brought in as a turnover specialist, the MNC's former innovation and engineering culture was significantly challenged as a result of new, predominantly short-termist financial measures of the HQ. Controlling and accounting functions were strongly upgraded throughout the conglomerate. As a result, the automotive supply division was no longer seen as the company's core business. This caused upheavals at the divisional HQ. Many managers left, and an even greater emphasis was placed on financial control.

The French CEO dealt proactively with the constraints of inadequate HQ resources for improving subsidiary productivity and quality standards. As a university trained materials scientist, who worked for 13 years in the R\&D department of a large German chemical company, the subsidiary manager was keen and capable of addressing the complex technical demands of car manufacturers. His professional experience as researcher, based on life long learning attitudes and strong analytical and design skills, enabled him to meet the challenges associated with the new mandate. Similar to the former case study, the managerial strategizing approach goes beyond just applying personal experiences and skills. By utilising local core competences of the firm and effectively applying limited financial resources, he managed to develop and establish a small local R\&D unit. Even when the local labor market did not provide the qualifications needed, his reputation and his social network, build up in the 30 years of his professional career, enabled him to attract new qualified personnel and motivate own staff to support his strategies. The successful management of the HQ-assigned mandate was also achieved through political 
coalition building, including with the labor force, where a stable and low-conflict atmosphere was established within the firm, inter alia by paying financial incentives, developing a stable core team of 250 employees and following a generally consensus-oriented management style when dealing with the works council and individual employees.

By managing challenges associated with the new mandate, some extremely promising technological innovations were achieved, and the French CEO issued an initiative to fully explore the potential of these technological achievements on a global scale. Being almost at the end of his career, it would seem that reputation, personal intrinsic motivation and care for the development of the local subsidiary, more than individual career ambitions, motivated the subsidiary manager's active engagement in taking this initiative and pursuing it in negotiations with the HQ. However, in line with previous frustrating experiences, he failed to get support from the HQ for his initiative to further explore and spread the subsidiary's local technological achievement globally. In line with the narrow financial control approach adopted by the HQ, this initiative was simply interpreted as being insufficient to realize the HQ's short-term profit goals, or as the French CEO put it: 'The HQ is not interested in measures that bring cash in 3 years; they want to see cash in 1.5 years.

\section{Case 3: An MNC internal market Initiative}

A young, ambitious Franco-German manager with considerable international job experience, a hierarchical career orientation and a financial professional background used his insider knowledge about innovative changes at a local competitor as well as the human resources of his French subsidiary to promote MNC-wide organization structure reforms aimed at increasing global efficiency. His goal was to build up power resources within the HQ and develop social skills to support a further 'financialization' of the MNC initiated by the HQ. This approach is clearly also focused on qualifying himself for a HQ career.

The 38-year-old ambitious CEO of the French regional company of a large German service firm, who was born in Germany, raised in France and studied in Germany, clearly displays a hierarchical career orientation. Following a trainee program at a large German bank and a short assignment as financial adviser at an engineering firm, he has worked at the German service MNC for about 10 years. So far, all of his assignments at the German MNC have been abroad, with the first 7 years spent in Asia. When the German MNC sold its Asian subsidiaries, he decided to stay with the MNC. He was appointed Chief Financial Officer of one of the MNC's French subsidiaries in 2002 and became CEO of the French regional office in 2003. 
The CEO does not consider this to be his final career step. His personal statements and the rather instrumental way he uses his subsidiary's mandate to participate in strategic decision making processes at the HQ level are indicative of his strong career ambitions. In addition to relationship management and corporate governance of the different subsidiaries operating in France, the relatively small French regional office is responsible for developing the MNC's corporate strategy for Western Europe, encompassing strategic tasks such as $M \& A$, lobbying, business intelligence. It is therefore attached to a much larger strategic development department in Germany. However, the most important initiative brought forward by the French CEO was focused not so much on further international expansion but rather on the internal 'market for ideas' for restructuring the MNC organization. Thus, the French CEO proposed an idea for streamlining organization processes in Germany, where more then $90 \%$ of the MNC's business activity takes place.

This initiative was inspired by recent organizational developments at a major French competitor. Based on new technologies, the French competitor turned its product-oriented organization into a customer-specific organization, unleashing a strong potential for rationalization (e.g. two full-fledged divisions had been condensed into one). Guided by his $\mathrm{HQ}$ career orientation and his professional experience as financial adviser, the French CEO carefully 'benchmarked' the organizational changes of the competitor. Based on a wide array of social contacts with the competitor's top management and local stakeholders such as trade unions, client organizations or regulation authorities, the CEO and his staff were able to conduct a solid analysis of the organizational changes of the French competitor. They drafted a detailed feasibility study, proposing a similar change for the home country based operations of the MNC.

This initiative developed in France, especially its effects on efficiency, were fundamentally in line with the overall strategy of the management board of the MNC, which was under strong pressures to increase shareholder value due to falling share prices. However, there was also strong opposition to this initiative, especially in the two divisions affected. Thus, before the French CEO officially approached the board of management with the initiative, he started to build up a large coalition of internal and external supporters. Since this task went clearly beyond the mandate of the French subsidiary and also exceeded his personal capacity and reputation, the French CEO decided to team up with the strategic development department in the HQ. Another key reason for this step was to share risks, since, in the view of the French CEO, coalition building always appears to be a rather open process: 'Even if you try hard, you never know exactly what impact your personal relationships and reputation will have'. In this case, teaming up with the strategic development department and maneuvering around more powerful actors in and outside the MNC seemed to be a viable approach. A coalition of about 20 people to support the initiative was formed, including almost all managing directors below the board of directors, several 
consultants and influential investment bankers. This coalition turned out to be powerful enough to convince the board of directors to implement the initiative.

So far, there have been no direct career rewards for the French CEO, who continued lobbying for 'his' initiative even after the strategic development department had formally taken over the task. However, his reputation at HQ, especially among the board of directors, has definitely increased.

\section{Agency in Subsidiary Initiatives: Some Theoretical Implications}

Taken together, the case studies covering the three basic types of subsidiary initiatives, as defined by Birkinshaw (1997), clearly illustrate that agency matters with regard to subsidiary initiatives. Our case studies show in some detail how the formation and translation of subsidiary initiatives by top foreign subsidiary managers are selectively and reflexively construed by integrating personal interests, different social practices within the MNC as well as institutional and socio-economic patterns relevant to the MNC and the subsidiary. These overall findings have some important implications for the literature on subsidiary initiatives, which will be dealt with below.

Based on the assumption that subsidiary development is to some extent a function of subsidiary initiative, we have seen a growing interest in furthering the understanding of subsidiary initiatives, especially the 1990s. As illustrated above, research has concentrated on three issues. First, research has been focused on classifying different types of subsidiary initiatives, distinguishing e.g. between local, global and MNC internal initiatives (Birkinshaw 1997) or between initiatives that aim at the creation of new, or the renewal of existing, subsidiary businesses (Verbeke et al. 2007). Second, research has extensively dealt with the question of what determines subsidiary initiatives. Third, the initiative process has also been examined. It is especially the two latter issues to which our findings contribute.

As summarized in table 2 above, the subsidiary initiative literature so far concludes that various determinants from the corporate (MNC) context, the subsidiary context as well as the local environment influence the development of subsidiary initiatives. However, despite the fact that some determinants suggest that the behavior of key foreign subsidiary managers is important (e.g. strong leadership, subsidiary management credibility), little attempt has been made so far to systematically elucidate the interests, local rationalities and behaviours of top foreign subsidiary managers with regard to subsidiary initiatives. Somewhat of an exception is a paper by Delany (2000) that elaborates on the overall motivation of subsidiary managers to take initiatives. Reasons given extend to foreign subsidiary managers' fear of charter losses 
and a general desire to develop the subsidiary to safeguard the current career position of the subsidiary manager. However these are universal behavioral assumptions that hardly cover the fact that key foreign subsidiary managers differ both with regard to their socio-political as well as their individual characteristics. Our case studies show that these factors (nationality, career ambition and orientation) and their interplay with contextual factors have a strong impact not only on the general motivation to take initiatives (1) but also on the kind of initiatives taken (2) and the way they are pursued in subsequent negotiations with the HQ (3).

(1) Looking at the key foreign subsidiary manager's general motivation to take initiatives, our case study evidence adds to the reasons given in the literature so far. While the study of Delany (2000) basically considers initiatives as means to protect vested rights (charters and career positions gained) our case studies demonstrate that actors follow a much more pro-active and forward looking approach with their initiatives. They engage in initiatives to serve their individual ambitions, which being high in all three cases, were of a quite different nature when related to their individual career orientation. While in case one the many initiatives taken by the manager are clearly the outflow of his strong entrepreneurial zest for action, 'going for a last big professional challenge' drove the manager in case two. 'Moving up the HQ career ladder' can be seen as the ultimate reason of the manager in case three to take initiative. This can be summarized as follows: Key foreign subsidiary managers take initiatives not only to protect vested rights but to pro-actively serve their individual career ambitions and orientations.

Table 3 about here

(2) The contexts in which a subsidiary operates (i.e. the corporate, subsidiary and local environment context) usually provide more than one opportunity to form an initiative. This is an important premise when considering the question of what specific initiatives key foreign subsidiary managers engage in. For instance, instead of proposing an internal initiative aimed at a far reaching restructuring of the home market operations, our manager in case three could instead have concentrated on initiatives aimed at the local French market. However, he did not do so because proposing a far reaching restructuring of the home market operations fit better with his pronounced hierarchical career orientation. This sheds some light on the crucial role of agency in defining which particular opportunities (having of course particular prospects of success) are turned into actual initiatives, an issue the literature so far has dealt with in far too broad terms. Refining the findings of the 'global staffing literature', our cases 
demonstrate that it is not only the nationality but also the subsidiary manager's career ambitions and career orientations that have a strong impact here. The cases elucidate in more detail how distinct hierarchical, professional or entrepreneurial career orientations have a strong differentiating impact on what particular opportunities key foreign subsidiary managers look for, take notice of and finally develop into initiatives by carefully orchestrating the MNC, the subsidiary and the local environment contexts.

(3) Socio-political and individual characteristics of key foreign subsidiary managers do play a role not only with regard to what initiatives they engage in, but also with regard to the way they pursue these initiatives. Here our findings contribute to the literature on the initiative process. This literature, dealing e.g. with distinct stages (Delany 1998) and forms of the initiative processes (Birkinshaw and Fry 1998), has produced contributions aimed at uncovering the role of agency in the initiative process. For example, a paper by Birkinshaw and Ridderstråle (1999) dealing with the 'corporate immune system' takes a closer look at the rationales and behaviors of $\mathrm{HQ}$ managers in the initiative process, while a more recent paper by Birkinshaw et al. (2007) describes what subsidiary managers can do to gain $\mathrm{HQ}$ attention. However, both contributions assume a universal behavior of the actors involved, based on their sub-organizational affiliation to either the $\mathrm{HQ}$ or the subsidiary. By focusing exclusively on subsidiary managers, our case studies provide a more differentiated picture. First, all our case studies strongly support the idea that social skills in mobilizing other actors' resources and building coalitions play an important role in intraorganizational decision making processes (Seo and Creed, 2002). In the case of subsidiary initiatives, such resource mobilization strategies can be directed towards actors in the subsidiary, in the local environment of the subsidiary, towards HQ actors or towards actors in third countries. However, the extent to which subsidiary managers follow these alternatives depends not only on contingent factors such as the support of local governments or the level of ethnocentricity in the HQ (see table 2). Instead, our case studies show that the resource mobilization strategies of key foreign subsidiary managers also depend on their individual socio-political and biographical backgrounds. For instance, the decision of the manager in case one to simultaneously follow a local as well as an HQ oriented resource mobilization strategy is clearly based on his nationality as much as on his previous interaction with the HQ, which developed in a specific way throughout his work life (starting with his early internship at the German MNC, followed by a successful enlargement of the business and by joint crisis management in the 1990ies). To sum up, it can be maintained that social agency also matters in the initiative process, given the strong impact that key foreign subsidiary managers' socio-political and biographical characteristics have on their resource mobilization strategies. 


\section{Conclusions}

This paper explores the impact of key foreign subsidiary managers' personal motivations in subsidiary initiatives and subsequent HQ-subsidiary negotiations. Based on empirical evidence of three case studies in German-owned subsidiaries in France, examining a local, a global and an MNC internal initiative, the paper demonstrates that the personal interests of key foreign subsidiary managers have a considerable impact on subsidiary initiatives. This relates to the general motivation of key foreign subsidiary managers to take initiatives, to their decision as to what particular opportunities they turn into initiative, and to the way they pursue these initiatives. Next, the paper revealed that personal motivations driving key local managers' subsidiary initiatives are strongly linked with their socio-political and biographical backgrounds. Specifically, the cases suggest that the different career orientations (hierarchical, professional and entrepreneurial) of key foreign subsidiary managers have a strong impact both on the general motivation to take initiatives as well as on the decision as to what opportunities are turned into initiates. The way key foreign subsidiary managers pursue these initiatives, most notably, what resources mobilization strategies they select, seems to be strongly shaped by their professional biographies, former career paths and current career interests, e.g. whether they are focused more on subsidiary development or on moving up the hierarchy into a HQ position.

Limitations of the study arise from the focus of analysis as well as from restrictions of presenting the initial results of an ongoing project. Taking a more systematic and more in-depth look at a broader variety of powerful actors involved in subsidiary initiatives, most notably actors in the HQ, would certainly broaden our understanding. The same is true for a more detailed process related analysis. Moreover, a more longitudinal research design, that is able to more extensively cover the biography of key actors as well as the biography of the HQ-subsidiary relationships involved, would help us to develop a better understanding of the historically developed potential for conflict and/or cooperation in subsidiary initiative processes. Finally, looking only at French subsidiaries of German firms strongly limits the insights that can be gained with regard to the institutional and other environment related influences at work. Basically the study can only trace how key subsidiary managers interpret and try to make (different) use of the home and host country contexts. A comparative research design to be adopted in future research (comparing initiative-taking in German subsidiaries in France and the UK) might lead to more far reaching results here.

Despite its limitations, our study has both practical and theoretical implications. Practical implications refer first to HR management and more precisely to global staffing policies. If MNCs really want to 'unleash innovation in foreign subsidiaries', as Birkinshaw and Hood (2001) have called for in a popular 
article, staffing policy should not only consider functional competences and nationality but also take a closer look at the biographical backgrounds, the career ambitions and most notably the career orientations of candidates, in order to ensure a sufficient number of subsidiary initiatives with a high potential. Second, the strong impact of key subsidiary managers' personal motivations and career aspirations on initiative-taking also implies an important control issue for the $\mathrm{HQ}$ in order to prevent subsidiary initiatives from ending in serious setbacks for the subsidiary or the MNC as a whole (as recently happened in the banking industry).

Theoretical implications mostly relate to the current debate about subsidiary initiative-taking. First and foremost, the paper demonstrates that social agency matters in subsidiary initiatives and that this needs to be integrated into the literature on subsidiary initiative. Second, elaborating on the personal motivation of key foreign subsidiary managers to engage in initiatives, the paper has added to the literature by demonstrating that the protection of vested rights is just one rationale, in addition to other rationales that have a more forward-oriented character, i.e. key foreign subsidiary managers taking initiatives to serve their individual career ambitions and orientations. A final contribution can be seen in the introduction of 'resource mobilization strategies' as a core concept to understand subsidiary initiative-taking. Resource mobilization strategies link actors to their various contexts and it is in particular these links that deserve more attention in future research.

The case studies demonstrate that mobilizing resources is a central element of subsidiary managers' strategizing related to subsidiary initiatives. First, this is an effect of the resource constraints with which subsidiaries are typically confronted as part of a larger entity (i.e the MNC). Second, the motivation to engage in resource mobilization strategies stems from the strong leverage effects these strategies can have, if actors with unique resources can be aligned. A first interesting question for further research would be to study the relationship between subsidiary resources (defined e.g. by the role a subsidiary has) and the resource mobilization strategies chosen by its managers. Related findings might add both to the literature on subsidiary specific advantages (Rugman and Verbeke, 2001) and to the literature dealing with subsidiary power in MNCs (Forsgren et al. 2005, Bouquet and Birkinshaw, 2008)

Second, the case studies provide ample evidence that subsidiary managers' resource mobilization strategies can take different directions. They can be directed towards actors in their own subsidiary (such as the work force or labor representation bodies) or towards actors in the local environment (e.g. customers, suppliers, government agencies, universities). At the same time however, they can also be directed towards the HQ and other units in the MNC, as well as to actors in foreign environments (e.g. foreign suppliers and customers). Here further research is needed to clarify the compatibility of 
resource mobilization strategies. While resource mobilization strategies towards certain sets of actors might go together well, strategies towards other sets of actors might lead to tensions or exclude each other. In addition to coming up with ideas on compatible and non-compatible resource mobilization strategies, research here could also contribute to the recent discussion on ambiguity management in MNCs (Kostova and Vora, 2007; Luo, 2005), focusing on how subsidiary managers orchestrate conflicting resource mobilization strategies.

A final interesting question for future research might address the actor related characteristics underpinning the various resource mobilization strategies. The case studies suggest that resource mobilization strategies are not equally available to all subsidiary managers and that the socio-political background as well as the career ambitions and orientations of the subsidiary manager play an important role. Other factors such as duration of the assignment, language proficiency, reputation and social capital might also play a role. The interplay of these factors deserves closer attention, to determine what resource strategies are within the reach of a particular subsidiary manager and what needs to be changed or worked on to make use of them. This research could contribute to the still underdeveloped literature on subsidiary strategy (Taggert, 1998; Birkinshaw, 2001) and strategy development in subsidiaries. 


\section{References}

Albert, M. (1991): Capitalisme contre Capitalisme, Paris: Seuil

Almond, P./Ferner, A. (2006) (eds): American Multinationals in Europe: Managing Employment Relations Across National Borders. OUP: Oxford:

Bartlett, C. A./Ghoshal, S. (1989): Managing across borders. The transnational solution. Boston: Harvard Business School Press

Becker-Ritterspach, F. (2006): The social constitution of knowledge integration in MNEs: A theoretical framework. Journal of International Management, No. 12, Vol. 3, pp. 358-377.

Bélanger, J./ Edwards P. (2006) : Towards a Political Economy Framework: TNCs as National and Global Players, in : Ferner, A., Quintanilla, J., Sánchez-Runde, C. (Eds.), Multinationals, Institutions and the Construction of Transnational Practices. Convergence and Diversity in the Global Economy. Palgrave Macmillan, Houndsmills, pp. 24-51

Birkinshaw, J (1997). Entrepreneurship in Multinational Corporations: The Characteristics of Subsidiary Initiatives, Strategic Management Journal, 18(3), pp. 207-229

Birkinshaw, J. (2000): Entrepreneurship in the Global Firm, London/Thousand Oaks/New Delhi

Birkinshaw, J. (2001): Strategy and management in MNE subsidiaries, in: Rugman, A./ Brewer T.L. (eds.): The Oxford handbook of international business, Oxford/New York: Oxford University Press, 380-401.

Birkinshaw, J / Fry, N. (1998) Subsidiary Initiatives to Develop new Markets, Sloan Manangement Review, Spring, 51-61

Birkinshaw, J. /Ridderstråle, J, (1999): Fighting the corporate immune system: a process study of subsidiary initiatives in multinational corporations. International Business Review. 8(2) 149-180.

Birkinshaw, J./Hood, N. (1998): Multinational subsidiary evolution: Capabilities and charter change in foreign-owned companies. In: Academy of Management Review, Vol. 23, No. 4, pp. 773-795

Birkinshaw, J./Hood, N. (2001): Unleash innovation in foreign subsidiaries, Harvard Business Review, March. Pp. 131-137

Black, J.S. /Gregersen, H.B. (1992): Serving two masters: managing the dual allegiance of expatriate employees, Sloan Management Review, 33, 4, 61-71.

Bolino, M.C. (2006): Expatriate assignment and intra-organizational career success: implications for individuals and organizations. In: Journal of International Business Studies, Vol. 38, 819-835.

Bouquet, C. /Birkinshaw, J (2008): Managing power in the multinational corporation: How low- power actors gain influence, Journal of Management Studies, 34,3, 477-508.

Buckley, P. J. (1996): The role of management in international business theory: A meta-analysis and integration of the literature on international business and international management. In: Management International Review, 36 (Special Issue), pp. 111-137 
Burns, Tom (1961/1962): Micropolitics: Mechanisms of Institutional Change. In: Administrative Science Quarterly, 6, 1961/1962, pp. 257-281

Casson, M. (1997): Information and organisation: A new perspective on the theory of the firm Oxford: Clarenden Press

Child, J./Faulkner, D./Pitkethly, R. (2001): The management of international acquisitions. Oxford: Oxford University Press

Chini, T./ Ambos. B. /Wehle, K. (2005): The Headquarters-subsidiaries Trench: Tracing Perception Gaps within the Multinational Corporation, European Management Journal, 23( 2), pp. 145-153

Clark, P. (2000): Organisations in Action. Competition between Contexts. London and New York: Routledge

Cooper, D. (2003): National culture, group composition, and the sharing of unique information. Paper presented at the Annual Academy of Management Conference. Seattle

Delany, E. (1998): Strategic development of multinational subsidiaries in Ireland. In Birkinshaw, J./Hood, N. (eds.): Multinational corporate evolution and subsidiary development. Macmillan Press: Houndsmill, Bas., pp. 239-267

Delany, E. (2000): Strategic development of multinational subsidiaries through subsidiary initiative taking. Long Range Planning, 33, pp. 220-244

Djelic, M.-L./Quack, S. (2003): Conclusion: Globalization as a Double Process of Institutional Change and Institution Building. In: Djelic, M.-L./Quack, S. (eds.): Globalization and Institutions. Redefining the Rules of the Economic Game. Cheltenham: Edward Elgar, pp. 302-333

Dörrenbächer, C. and Gammelgaard, J. (2006): Subsidiary role development: The effect of micro-political headquarters-subsidiary negotiations on the product, market and value-added scope of foreign-owned subsidiaries, Journal of International Management, 12/3: pp. 266-283

Dörrenbächer, C. (2004): Fleeing or Exporting the German Model? The Internationalization of German Multinationals in the 1990s. In: Competition \& Change, Vol. 8, No. 4, pp. 443- 456

Dörrenbächer, C./Geppert, M. (2006): Micro-politics and conflicts in multinational corporations: Current debates, re-framing, and contributions of this special issue, Journal of International Management, 12/3: pp. 251-265.

Dunning, J.H. (1979): Explaining Changing Patterns of International Production: In Defence of the Eclectic Theory. In: Oxford Bulletin of Economics and Statistics, pp. 269-295

Edwards, T./Kuruvilla, S. 2005. 'International HRM: National Business Systems, Organisational Politics and the International Division of Labour in Global Value Chains', International Journal of Human Resource Management, 16, 1, 1-21

Egelhoff, W. G. (1993): Information-processing theory and the multinational corporation. In: Ghoshal, S./Westney, E. D. (eds): Organization theory and the multinational. London: Macmillan, pp. 182-210

Egelhoff, W. G./Gorman, L./McCormick, S (1998): Using technology as a path to subsidiary development. In: Birkinshaw, J./Hood, N. (eds): Multinational corporate evolution and subsidiary development. Macmillan Press, Houndsmill, Bas., pp. 213-238 
Ferner, A. (2000): The underpinnings of 'bureaucratic' control systems: HRM in European Multinationals. In: Journal of Management Studies, Vol. 37, No. 4, pp. 521-539

Ferner, A., Quintanilla, J. and Sánchez-Runde, C. (2006): 'Introduction: Multinationals and the Multilevel Politics of Cross-National Diffusion', in Ferner, A., Quintanilla, J. and Sánchez-Runde, C. (eds.), Multinationals, Institutions and the Construction of Transnational Practices. Convergence and Diversity in the Global Economy, Basingstoke: Palgrave, 1-23.

Fligstein, N. (1990): The transformation of Corporate Control. Cambridge/MA: Harvard University Press

Florida, R.(1997): The globalization of R\&D: results of a survey of foreign-affiliated R\&D laboratories in the USA. Research Policy, 26, pp. 85-103

Forsgren, M. (1990): Managing the Intrenational Multi-centre Firm: Case Studies from Sweden, In: European Management Journal, 8, pp.261-267

Forsgren, M./Holm, U.,/Johanson, J. (2005): Managing the embedded multinational: A business network view. Cheltenham: Edward Elgar

Geppert, M./Williams, K./Matten, D. (2003): The social construction of contextual rationalities in MNCs: An Anglo-German comparison of subsidiary choice. In: Journal of Management Studies, Vol. 40, No. 3, pp. 617-641

Gunnigle, P./Murphy, K. R./Cleveland, J. N./Heraty, N./Morley, M. (2002): Localization in Human Resource Management: Comparing American and European Corporations. In: Hitt, M. A./Cheng, J. L. C. (eds.): Managing transnational firms: Resources, market entry and strategic alliances. Greenwich, CT: JAI Press

Hall, D. T. (2002): Careers in and out of organizations. Thousand Oaks: Sage

Hall, D. T./Nougain, K. (1968): An Examination of Maslow's Need Hierarchy in an Organizational Setting. In: Organizational Behavior and Human Performance, 3, pp. $12-35$

Harvey, M. G./Novicevic, M. M./Speier, C. (1999): Inpatriate Managers: How to Increase the Probability of Success. In: Human Resource Management Review, Vol. 9, Nr. 1, pp. 151-181

Harzing, A.-W. (1999): Managing the Multinationals. An International Study of Control Mechanisms. Cheltenham/Northampton: Edward Elgar

Harzing, A.-W./Sorge, A. (2003): The Relative Impact of Country of Origin and Universal Contingencies on Internationalization Strategies and Corporate Control in Multinational Enterprises: Worldwide and European Perspectives. In: Organizational Studies, Vol. 24, No. 2, pp. 187-214

Hood, N./Young, S./Lal, D. (1994): Strategic evolution within Japanese manufacturing plants in Europe: UK evidence. International Business Review, Vol. 3, No. 2, pp. $97-122$

Jarillo, J. C./Martínez, J. I. (1990): Different roles for subsidiaries: the case of multinational corporations in Spain. In: Strategic Management Journal, 11, pp. 501-513

Johanson, J./Vahlne, J.-E. (1977): The Internationalization Process of the Firm - a Model of Knowledge Development and Increasing Foreign Market Commitments. In: Journal of International Business Studies, Vol. 8, No. 1, pp. 23-32 
Jürgens, U./Naumann, K./Kupp, J. (2000): Shareholder Value in an Adverse Environment: The German Case. In: Economy and Society, Vol. 29, No. 1, pp. 54-79

Katzenstein, P. J. (1980): Problem or Model? West Germany in the 1980s. In: World Politics,, 32, pp. 577-98

Kleiner. T. (2004) : Building up an asset management industry: Anglo-Saxon logic in France, In: Djelic, M.-L./Quack, S. (eds.): Globalization and Institutions. Redefining the Rules of the Economic Game. Cheltenham: Edward Elgar, pp. 5782

Kostova, T. (1999).:Transnational Transfer of Strategic Organizational Practices: A Contextual Perspective. Academy of Management Review, 24(2), pp. 308-324.

Kostova, T./Vora, D. (2007): A model of dual organizational identification in the context of the multinational enterprise. Journal of Organizational Behaviour, 28, 327-350.

Kristensen P.H /Zeitlin, J. (2005): Local players in global games. The strategic constitution of a multinational corporation, Oxford: OUP

Küpper, W./Felsch, A. (2000): Organisation, Macht und Ökonomie. Mikropolitik und die Konstitution organisationaler Handlungssysteme. Wiesbaden: Westdeutscher Verlag

Lee, R./Lawrence, R. (1985): Organizational Behaviour. Politics at Work. London: Hutchinson

Loveridge, R. (2006): Embedding the Multinational Enterprise: The Micro-processes of Institutionalisation in Developing Economies. In: Geppert, M./Mayer, M. (eds.): Global, National and Local Practices in Multinational Companies, pp. 189-219

Luo, Y. (2005): Toward Coopetition within a Multinational Enterprise: A Perspective from Foreign Subsidiaries, Journal of World Business, 40, 71-90.

March, James G. (1962): The business firm as a political coalition. In: The Journal of Politics, 24, pp. 662-678

Marquez, L. M. (2005): The implementation of control mechanisms in European multinationals: A comparison of British and German subsidiaries in Venezuela. Doctoral Thesis. University of Warwick

Mayrhofer, W. (1996): Mobilität und Steuerung in international tätigen Unternehmen. Eine theoretische Analyse, Stuttgart: Schäffer-Poeschel

Morgan, G. (2001): The Multinational Firm. Organizing across Institutional and National Divides. In: Morgan, G./Kristensen, P. H./Whitley, R. (eds.): The Multinational Firm. Organizing across Institutional and National Divides. Oxford: OUP , pp. 124

Morgan, G. /Kristensen, P.H. (2006) The contested space of multinationals: Varieties of institutionalism, varieties of capitalism, Human Relations, 59: pp.1467-1490

Moss Kanter, R. (1989): Careers and Wealth of Nations: A Macro-perspective on the Structure and Implications of Career forms. In: Arthur, M. B. et al. Handbook of Career Theory. Cambridge: Cambridge University Press pp. 506-521

Noorderhaven, N. G./Harzing, A.-W. (2003): The "Country-of-origin-effect" in multinational corporations: Sources, mechanisms and moderating conditions. In: Management International Review, Vol. 42, No. 2, pp. 47-66 
Ortmann, G. (1988): Macht, Spiel, Konsens. In: Küpper/Ortmann (eds): Mikropolitik. Rationalität, Macht und Spiele in Organisationen. Westdeutscher Verlag, pp. 1326

Pearce, R. (1999): The Evolution of Technology in Multinational Enterprises: The Role of Creative Subsidiaries. In: International Business Review, 8, pp. 125-148

Peltonen, T. (1993): Managerial Career Patterns in Multinational Corporations: An Organizational Capability approach, European Management Journal, 11(2), pp. 248-257

Penrose, E. (1959): The Theory of the Growth of the Firm. Oxford: OUP

Peterson, R. B./Napier, N./Shim, W. S. (1996): Expatriate Management: The Differential Role of National Multinational Corporation Ownership. In: The International Executive, 38, pp. 543-562

Peterson, R. B./Napier, N./Shim, W. S. (2000): Expatriate Management: A Comparison of MNCs across Four Parent Countries. In: Thunderbird International Business Review, 42, pp. 145-166

Pfeffer, J. (1993): Organizational demography. Research in Organizational Behaviour, 5, pp. 299-357

Prahalad, C. K./ Doz, Y. (1987): The multinational mission: Balancing local demands and global vision. New York: Free Press

Rugman, A./Douglas, S. (1986): The strategic management of multinationals and world product mandating. In: Etemad, H./Dulude, L. S. (eds): Managing the multinational subsidiary: response to environmental changes and to host nation R\&D policies. Beckenham, Kent: Croom Helm, pp. 90-101.

Rugman, A.M. Nerbeke, A. (2001): Subsidiary-specific Advantages in Multinational Enterprises, Strategic Management Journal, 22, 237-250

Ruigrok, W./van Tulder, R. (1995): The Logic of International Restructuring. London/New York: Routledge

Schein, E.H. (1978/1990): Career Anchors (Revised). San Diego: University Associates

Scullion, H/ Collings, D.G (2006) Global Staffing, London/New York: Routledge

Seo, M.G./Creed, W. E. D. (2002): Institutional Contradictions, Praxis, and Institutional Change: A Dialectical Perspective, In: Academy of Management Review, Vol. 27, No. 2, pp. 222-247

Sharpe, D. R. (2001): Globalization and Change: Organizational Continuity and Change within a Japanese Multinational in the UK. In: Morgan, G./Kristensen, P. H./Whitley, R. (eds.): The Multinational Firm. Organizing Across Institutional and National Divides. Oxford: OUP, pp. 196-222

Sorge, A. (2005): The Global and the Local: Understanding the Dialectics of Business Systems, Oxford: OUP

Stahl, G. K./ Miller, E. L./ Tung, R. L. (2002): Toward the boundaryless career: a closer look at the expatriate career concept and the perceived implications of an international assignment. In: Journal of World Business, 37, pp. 216-227

Streeck, W. (1997): German Capitalism: Does it exist? Can it survive? In: Crouch, C.I Streeck, W: (eds.) Political economy of modern capitalism, London: Sage, pp-3354 
Taggert, J. H. (1998): Strategy Shifts in MNC Subsidiaries. In: Strategic Management Journal, 19, pp. 663-681

Tainio, R./Huolman, M./Pulkkinen, M. (2001): The internationalization of capital markets: How international Institutional Investors are restructuring Finnish Companies. In: Morgan, G./ Kristensen, P. H./Whitley, R. (eds.): The Multinational Firm. Organizing across Institutional and National Divides. Oxford: OUP, pp. 153-171

Tarique, I., Schuler, R., and Gong, Y. (2006), "A Model of Subsidiary Staffing Composition," International Journal of Human Resource Management, 17,2, 207-224

Teece, D. J. (1992): Foreign Investment and Technological Development in Silicon Valley. In: California Management Review, Vol. 34, No. 2 (Winter), pp. 88-106

Tempel, A./Walgenbach, P. (2003): Global standardization of organisational forms and management practices?: Combining American and European institutionalism. Paper presented at the 3rd Conference of the European Academy of Management, Milan

Useem, M. (1996): Investor Capitalism, New York: Basic Books

Verbeke, A. / Chrisman, J.J. /Yuan, W. (2007): A Note on Strategic Renewal and Corporate Venturing in the Subsidiaries of Multinational Enterprises, in: Entrepreneurship Theory and Practice, July 2007 pp.585-299.

Vernon, R. (1966): International investment and international trade in the product cycle. In: Quarterly Journal of Economics, 80, pp. 190-207

Vitols, S. (2004): Continuity and Change: Making Sense of the German Model. In: Competition \& Change, Vol. 8, No. 4, pp. 331-338

Watson, W. E./Kumar, K./Michaelsen, L. K. (1993): Cultural diversity's impact on group process and performance: Comparing culturally homogeneous and culturally diverse task groups. In: The Academy of Management Journal, Vol. 36, No. 3, pp. 590-602

Weick, K. E. (1995): Sensemaking in Organizations. Thousand Oaks: Sage

Westney, D. E. (1993): Institutionalization theory and the multinational corporation, in Ghshal, S./Westney, D. E. (eds.): Organization theory and the multinational corporation, Basingstoke: Macmillan, pp. 53-76

Westney, D. E./Zaheer, S. (2001): The multinational enterprise as an organization. In: Rugman, a. M./Brewer, T. (eds.): The Oxford handbook of international business. Oxford: OUP, pp. 349-379

White, R. E./Poynter, T. A. (1984): Strategies for foreign-owned subsidiaries in Canada. Business Quarterly, 49(2), pp. 59-69

Whitley, R. (2001): How and why are international firms different? The consequences of cross-border managerial coordination for firm characteristics and behaviour. In: Morgan, G./Kristensen, P. H./Whitley, R. (eds.): The Multinational Firm.

Organizing Across Institutional and National Divides. Oxford: OUP, pp. 27-68 
Table 1: Contributions and Limits of Evolutionary and Comparative Institutionalist MNC Research

\begin{tabular}{|l|l|l|l|}
\hline $\begin{array}{l}\text { Basic } \\
\text { Approach }\end{array}$ & $\begin{array}{l}\text { Variants I } \\
\text { Authors }\end{array}$ & $\begin{array}{l}\text { Overall } \\
\text { Contribution }\end{array}$ & $\begin{array}{l}\text { Contributions and Limits } \\
\text { with regard to the study of } \\
\text { agency in subsidiary } \\
\text { initiatives }\end{array}$ \\
\hline $\begin{array}{l}\text { Evolutionary } \\
\text { approach }\end{array}$ & $\begin{array}{l}\text { Bartlett \& } \\
\text { Ghoshal (1989) }\end{array}$ & $\begin{array}{l}\text { MNCs are shaped by } \\
\text { business } \\
\text { environment } \\
\text { contingencies } \\
\text { industry dynamics) }\end{array}$ & $\begin{array}{l}\text { HQ is seen as the sole actor. HQ's } \\
\text { behavior is seen as being shaped by } \\
\text { industry dynamics. Key subsidiary } \\
\text { actors are considered as unimportant } \\
\text { and are not looked at. }\end{array}$ \\
\hline $\begin{array}{l}\text { Evolutionary } \\
\text { approach }\end{array}$ & $\begin{array}{l}\text { White \& } \\
\text { Poynter (1984) }\end{array}$ & $\begin{array}{l}\text { MNC are shaped by } \\
\text { HQ strategies and } \\
\text { subsidiary } \\
\text { entrepreneurship }\end{array}$ & $\begin{array}{l}\text { HQ and subsidiaries are seen as } \\
\text { relevant actors. Their behavior is } \\
\text { basically seen as being shaped by the } \\
\text { different environmental contingencies. } \\
\text { Key subsidiary actor characteristics } \\
\text { are not looked at. }\end{array}$ \\
\hline $\begin{array}{l}\text { Comparative } \\
\text { Institutionali } \\
\text { sm }\end{array}$ & $\begin{array}{l}\text { Ruigrinshaw \& van } \\
\text { Tulder (1995) }\end{array}$ & $\begin{array}{l}\text { Managerial decisions } \\
\text { in MNCs are shaped } \\
\text { by home country } \\
\text { institutional settings }\end{array}$ & $\begin{array}{l}\text { HQ is seen as the dominant actor. HQ } \\
\text { behavior is seen as being entirely } \\
\text { shaped host country institutional } \\
\text { settings. Key subsidiary actors are } \\
\text { considered as unimportant and are } \\
\text { not looked at. }\end{array}$ \\
\hline $\begin{array}{l}\text { Comparative } \\
\text { Institutionali } \\
\text { sm }\end{array}$ & $\begin{array}{l}\text { Westney } \\
(1993)\end{array}$ & $\begin{array}{l}\text { Managerial decisions } \\
\text { in MNCs are shaped } \\
\text { by differences in the } \\
\text { institutional settings } \\
\text { between home and } \\
\text { host countries }\end{array}$ & $\begin{array}{l}\text { HQ and subsidiaries are seen as } \\
\text { relevant actors. Their behavior is } \\
\text { seen as being shaped by home and } \\
\text { respectively host country institutional } \\
\text { settings. Key subsidiary actor } \\
\text { characteristics are not looked at. }\end{array}$ \\
\hline
\end{tabular}

Source: own exhibition 
Table 2: Determinants of Subsidiary Initiatives

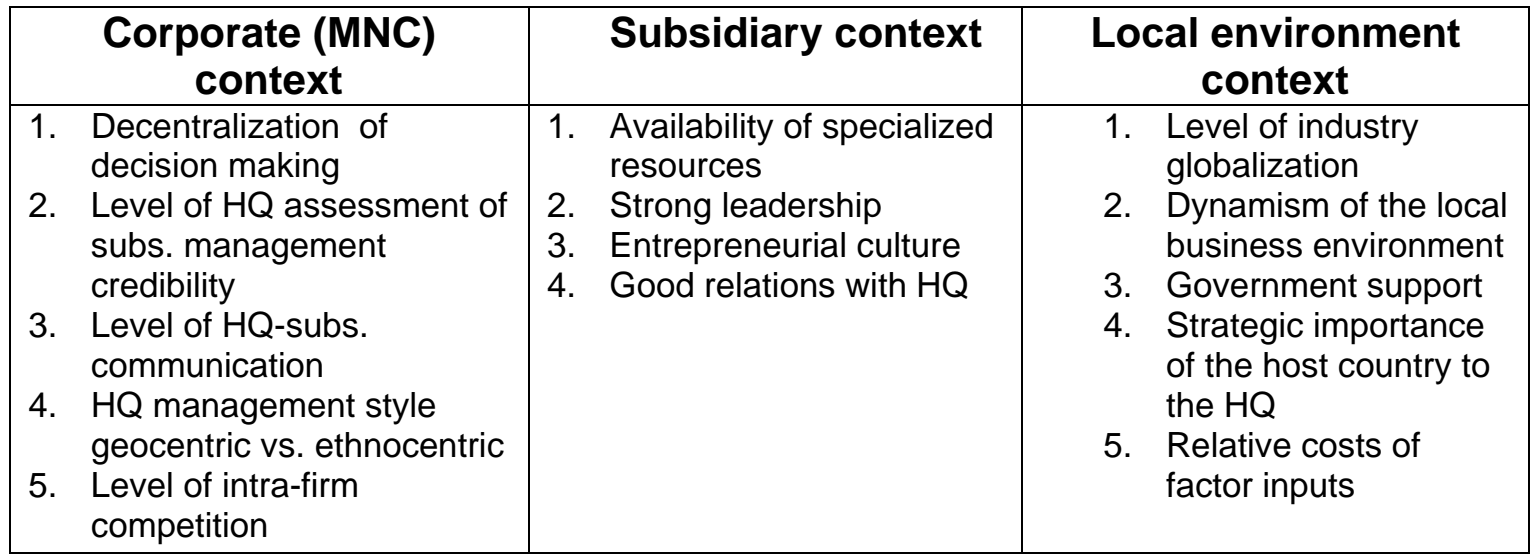

Source: Own exhibition based on Verbeke et al. 2007 
Table 3: The value added of studying key subsidiary managers and their behavior in subsidiary initiative-taking

\begin{tabular}{|l|l|l|}
\hline $\begin{array}{c}\text { Elucidates individual } \\
\text { motivations to take } \\
\text { initiatives }\end{array}$ & $\begin{array}{c}\text { Instructs on what } \\
\text { opportunities are } \\
\text { turned into initiatives }\end{array}$ & $\begin{array}{l}\text { Gives insights into } \\
\text { resource mobilization } \\
\text { strategies }\end{array}$ \\
\hline $\begin{array}{l}\text { Protect vested rights } \\
\text { (such as subsidiary } \\
\text { charters and career } \\
\text { positions) }\end{array}$ & $-\begin{array}{l}\text { Feasibility of the initiative } \\
-\begin{array}{l}\text { Prospects of success } \\
\text { Fro-actively serve } \\
\text { individual career } \\
\text { ambitions and orientations career ambitions }\end{array}\end{array}$ & $\begin{array}{l}\text { Direction of resource } \\
\text { mobilization strategies } \\
\text { (towards the subsidiary, } \\
\text { the local environment, the } \\
\text { HQ or a third country } \\
\text { environment) } \\
\text { Strong influence of the } \\
\text { actor's socio-political and } \\
\text { biographical background. }\end{array}$ \\
\hline
\end{tabular}

Source: Own exhibition 
Figure 1: The Role of Social Agency in Subsidiary Initiatives and Development

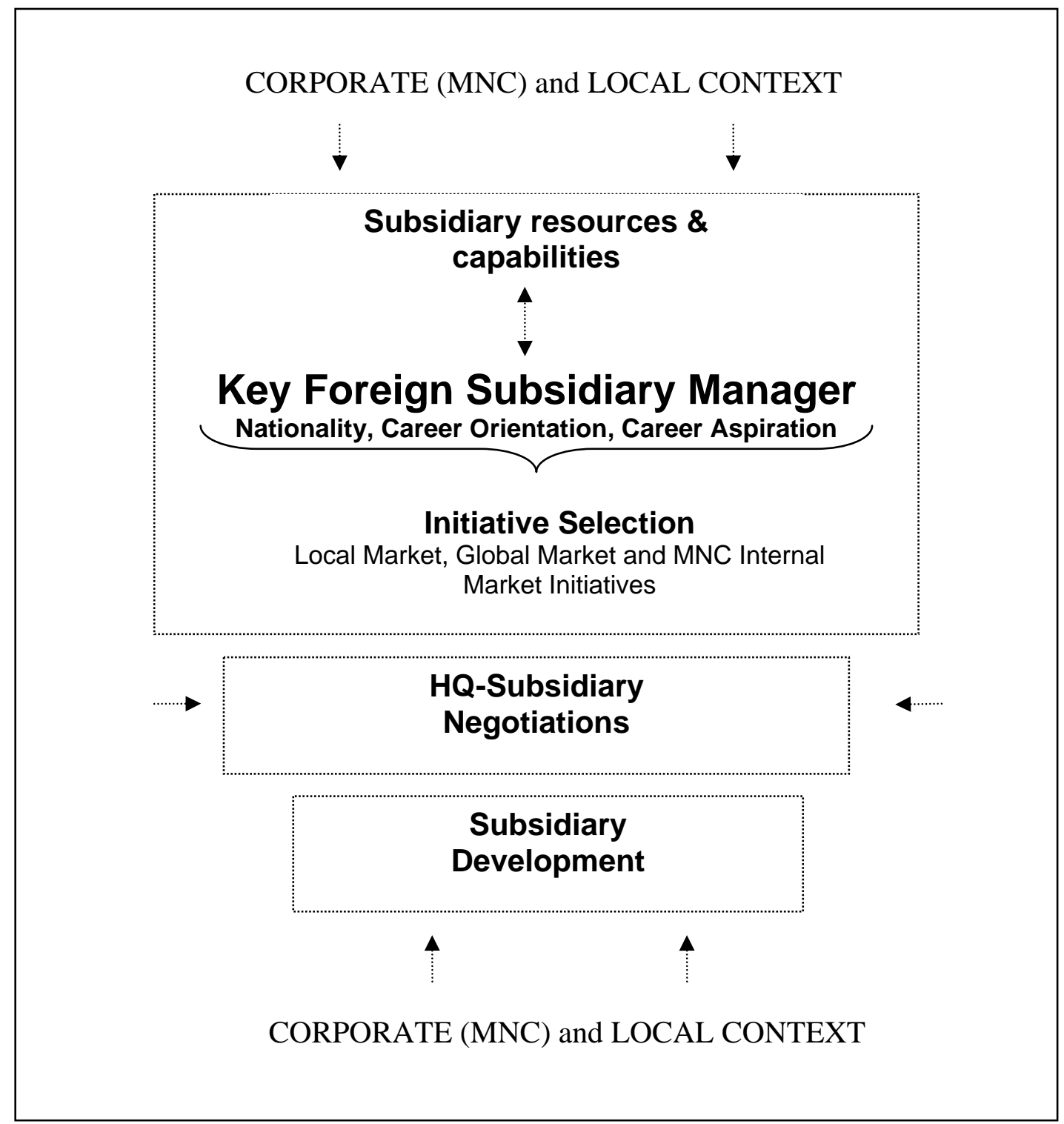

